\title{
Penerapan Data Mining Dalam Meningkatkan Mutu Perawatan dan Perbaikan Perlengkapan Alat-Alat Kapal Laut Menerapkan Metode K-Means Clustering
}

\author{
Yulifa Esfana Putri Sinaga, Garuda Ginting, Melda Panjaitan \\ Program Studi Teknik Informatika, Universitas Budi Darma, Medan, Indonesia \\ Email: yulifasinaga@gmail.com \\ Submitted: 03/12/2020; Accepted: 26/02/2021; Published: 30/05/2021
}

\begin{abstract}
Abstrak-Penelitian ini bertujuan untuk mengusulkan dalam menjalankan kegiatan berlayar pada kapal KN. Arcturus pada setiap minggu, sehingga kegiatan perawatan dan pemeliharaan perlu dilakukan dengan baik dan dijadwalkan agar tidak mengganggu kegiatan produksi yang sedang berlangsung. Kerusakan mesin saat ini masih terhitung tinggi dan memerlukan waktu perbaikan yang cukup lama, yang diusulkan adalah preventive maintenance dengan menggunakan teknik Clustering. Metode yang digunakan adalah K-Means Clustering. Dengan menggunakan metode ini data-data yang telah didapatkan dapat dikelompokkan ke dalam beberapa cluster, berdasarkan kemiripan dari data-data tersebut, sehingga data-data yang memiliki karakteristik yang sama dikelompokkan dalam satu cluster dan yang memiliki karakteristik yang berbeda dikelompokkan dalam cluster yang lain. Berlimpahnya data tersebut dapat kita manfaatkan untuk mencari informasi yang tersembunyi dari data-data tersebut. Untuk dapat mengetahui informasi yang tersembunyi dari data-data tersebut, maka perlu dilakukan pengolahan terhadap data-data tersebut. Proses pengolahan data tersebut disebut juga dengan Data Mining. Dengan adanya pngelompokan ini maka akan mengetahui hasil dari data yang dianalisa.
\end{abstract}

Kata Kunci: Preventive Maintenance; Data Mining; Clustering; K-Means

Abstract-This study aims to propose in carrying out sailing activities on the KN. Arcturus ship every week, so that maintenance and maintenance activities need to be carried out properly and scheduled so as not to interfere with ongoing production activities. The current machine breakdown is still relatively high and requires a long repair time, what is proposed is preventive maintenance using the Clustering technique. The method used is K-Means Clustering. By using this method, the data that has been obtained can be grouped into several clusters, based on the similarity of these data, so that data that has the same characteristics are grouped into one cluster and those that have different characteristics are grouped into another cluster. We can use the abundance of data to find hidden information from these data. In order to find out the hidden information from these data, it is necessary to process the data. The data processing process is also known as data mining. With this grouping it will know the results of the analyzed data.

Keywords: Preventive Maintenance; Data Mining; Clustering; K-Means

\section{PENDAHULUAN}

Kapal merupakan alat transportasi perhubungan manusia dan pegiriman barang suatu daerah ke daerah lain, bahkan sampai dari suatu negara ke negara lain. Kapal dapat dikelompokkan dalam bermacam-macam jenis, karena didalam golongan kapal dibedakan berdasarkan bahan pembuat kapal, seperti yang ada pada alat penggeraknya, fungsi dan kegunaan kapal.

Kapal yang digunakan untuk mengangkut barang atau penumpang, pada dasarnya kapal yang digunakan untuk semua kegiatan baik untuk mengangkut barang atau penumpang serta kegiatan lainnya akan memerlukan sistem keamanan dan alat-alat kapal yang lainnya pada saat kapal beroperasi.Karena kapal di anggap sebagai sarana transportasi yang sangat berperan penting. Oleh karena itu, pengoperasian alat angkutan dan alat navigasi,mesin kapal serta alat keselamatan pada kapal memerlukan perawatan dan perbaikan yang baik.

$K$-Means mempunyai kemampuan mengelompokkan data dalam jumlah yang cukup besar dengan waktu komputasi yang relatif dan efisien. Namun K-Means mempunyai kelemahan yang diakibatkan oleh penentuan pusat awal cluster. Hasil cluster yang terbentuk dari metode $K$-Means ini sangatlah tergantung pada inisiasi pusat awal cluster yang diberikan[1], [2].

\section{METODE PENELITIAN}

\subsection{Data Mining}

Istilah data mining memiliki beberapa padanan seperti Knowledge discovery ataupun pattern recogniton. Kedua istilah tersebut yang sebenarnya memiliki ketepatannya masing-masing. Istilah dari Knowledge discovery atau (penemuan pengetahuan) tepat karena tujuan utama dari data mining memang untuk mendapatkan pengetahuan yang masih tersembunyi didalam bongkahan data. Istilah pattern recogniton atau (pengenalan pola) tepat untuk digunakan karena pengetahuan yang hendak digali memang berbentuk pola-pola yang mungkin juga yang masih perlu digali dari dalam bongkahan data yang tengah dihadapi[3].

\subsection{Clustering}


Biasanya proses clustering dalam tujuan ini hanya sebagai proses awal untuk kemudian dilanjutkan dengan pekerjaan ini seperti summarization (rata-rata, standar deviasi), pelabelan kelas pada setiap kelompok untuk kemudian digunakan sebagai data latih klasifikasi, dan sebagainya. Sementara jika tujuannya untuk penggunaan, biasanya tujuan utama untuk mencari prototype cluster yang paling representativeterhadap data dan memberikan abstraksi dan setiap objek data dalam cluster dimana sebuah data terletak didalamnya[3].

\subsection{Algoritma K-Means}

K-means merupakan salah satu teknik pengelompokan yang bekerja berdasarkan partitioned clustering. Prinsip kerja dari pengelompokan hierarchical clustering dilakukansecara bertahap. Dan disetiap iterasi dari pengelompokan hierarchical clustering hanya ada satu pemilihan penggabungan suatu item terhadap item lainnya. Sedangkan prinsip kerja dari pengelompokan partitioned clustering adalah mengelompokkan item secara acak karena dipengaruhi centroid. Dan dalam setiap iterasi dari pengelompokkan partitioned clustering dapat memungkinkan untuk terjadinya lebih dari satu pemilihan item yang akan digabungkan[4]-[7].

K-Means merupakan salah satu metode data clustering non hirarki yang berusaha mempartisi data yang ada ke dalam bentuk satu atau lebih cluster atau kelompok. Metode ini mempartisi ke dalam cluster atau kelompok sehingga data yang memiliki karakteristik yang sama (High intra class similarity) dikelompokkan ke dalam satu cluster yang sama yang memiliki karakteristik yang berbeda (Law inter class similarity) dikelompokkan pada kelompok yang lain. Proses clustering dimulai dengan mengidentifikasi data yang akan dicluster, $\mathrm{X}_{\mathrm{ij}}(\mathrm{i}=1, \ldots, \mathrm{n}$; $\mathrm{j}=1, \ldots, \mathrm{m}$ ) dengan $\mathrm{n}$ adalah jumlah data yang akan dicluster dan $\mathrm{m}$ adalah jumlah variabel. Pada awal iterasi, pusat setiap cluster ditetapkan secara bebas (sembarang), $\mathrm{C}_{\mathrm{kj}}(\mathrm{k}=1, \ldots, \mathrm{k} ; \mathrm{j}=1, \ldots, \mathrm{m})$. Kemudian dihitung jarak antara setiap data dengan setiap pusat cluster. Untuk melakukan perhitungan jarak data ke-i $\left(\mathrm{x}_{\mathrm{i}}\right)$ pada pusat cluster ke-k $\left(\mathrm{c}_{\mathrm{k}}\right)$, diberi nama $\left(\mathrm{d}_{\mathrm{ik}}\right)$, dapat digunakan formula Euclidean, seperti pada persamaan (1), yaitu:

$$
\left.\mathrm{d}_{\mathrm{ik}}=\sqrt{\sum_{j=1}^{m}\left(x_{i j}\right.}-c_{i j}\right)^{2}
$$

Suatu data akan menjadi anggota dari cluster ke-k apabila jarak data tersebut ke pusat cluster ke-k bernilai paling kecil jika dibandingkan dengan jarak ke pusat cluster lainnya. Hal ini dapat dihitung dengan menggunakan persamaan (2) selanjutnya, kelompokkan data-data yang menjadi anggota pada setiap cluster.

$$
\operatorname{Min} \sum_{k=1}^{k} d_{i k}=\sqrt{\sum_{j=1}^{m}}\left(x_{i j}-c_{i j}\right)^{2}
$$

Nilai pusat cluster yang baru dapat dihitung dengan cara mencari nilai rata-rata dari data-data yang menjadi anggota pada cluster tersebut, dengan menggunakan rumus pada persamaan (3):

$$
\mathrm{c}_{\mathrm{ij}}=\frac{\sum_{i=1}^{p} x_{i j}}{p}
$$

Dimana $\mathrm{x}_{\mathrm{ij}} \in$ cluster $\mathrm{ke}-\mathrm{k}$

$\mathrm{p}$ = banyaknya anggota cluster ke $\mathrm{k}$

Langkah-langkah pada proses clustering dengan menggunakan algoritma K-Means, adalah sebagai berikut:

1. Menentukan Jumlah Cluster: Jumlah cluster yang ditentukan untuk mengelompokan data pada penelitian ini sebanyak 2 cluster.

2. Menentukan Centroid Pusat awal cluster (centroid) ditentukan secara random atau acak.

3. Menghitung Jarak dari Centroid Menghitung jarak antara titik centroid dengan titik tiap objek dengan menggunakan Euclidian Distance.

4. Alokasikan masing-masing objek ke centroid terdekat. Dan untuk mengalokasikan objek ke dalam masingmasing padacluster dengan cara mengelompokkan berdasarkan jarak minimum objek ke pusat cluster.

\section{HASIL DAN PEMBAHASAN}

Perawatan adalah kegiatan yang dilaksanakan secara terus menerus atau berkesinambungan terhadap peralatan dan perlengkapan agar kapal selalu dalam keadaan baik dilaut dan siap operasi. Dalam suatu usaha untuk dapat terus menggunakan fasilitas agar kegiatan operasi dapat berlangsung dibutuhkan kegiatan perawatan. Kegiatan perawatan bertujuan untuk memperbaiki performance mesin,baik untuk jangka pendek atau jangka panjang. Untuk jangka pendek diharapkan adanya kenaikan dalam produktifitas mesin,dan untuk jangka panjang diharapkan umur mesin lebih panjang ( dibandingkan jika tidak dirawat dengan baik). Adapun yang merupakan masalah teknis dalam hal ini adalah persoalan - persoalan yang menyangkut kemungkinan-kemungkinan timbulnya kemacetan atau kerusakan yang disebabkan karena kondisi fasilitas atau peralatan operasi yang tidak baik.

Sedangkan permasalahan untuk keselamatan maka perawatan ditingkatkan dalam hal ini adalah masalah yang menyangkut bagaimana usaha yang harus dilakukan agar kegiatan perawatan yang dibutuhkan secara teknis dapat efisien. Dataset yang digunakan dalam penelitian ini adalah menggunakan dataset dari Instansi Distrik Navigasi data yang digunakan dalam penelitian ini adalah data perencanaan perawatan dan perbaikan perlengkapan alat-alat kapal, yang didapatkan dari instansi Distrik Navigasi pada kapal KN.Arcturus.

Berikut ini adalah data nama perlengkapan alat-alat kapal yaitu sebanyak 25 komponen alat yang didapatkan dari studi kasus yang telah dikelompokkan. 
Tabel 1. Data set atau data awal

\begin{tabular}{clccc}
\hline No & Perlengkapan Alat-Alat Kapal & $\begin{array}{c}\text { Jam Operasi } \\
\text { Alat }\end{array}$ & $\begin{array}{c}\text { Frekuensi Kerusakan } \\
(\%)\end{array}$ & $\begin{array}{c}\text { Perencanaan } \\
\text { Kegiatan Rutin }\end{array}$ \\
\hline 1. & Daun/Tongkat Kemudi & 10 & 0,3 & Perawatan \\
2. & Jangkar/Rantai Sistem & 12 & 0,25 & Perawatan \\
3. & Sistem Pengeras Suara & 8 & 0,5 & Perbaikan \\
4. & Gps navigator & 12 & 0,4 & Perawatan \\
5. & Navigational Echo Sounder & 24 & 0,6 & Perbaikan \\
6. & Sistem Pemadam & 2 & 0,1 & Perbaikan \\
7. & Tetrahed Radar Reflector & 12 & 0,15 & Perawatan \\
8. & Suling Kapal & 2 & 0,2 & Perbaikan \\
9. & Radar Kapal & 10 & 0,25 & Perawatan \\
10. & Sekat & 7 & 0,3 & Perbaikan \\
11. & Bolder & 5 & 0,45 & Perawatan \\
12. & Transmitter & 3 & 0,25 & Perbaikan \\
13. & Clinometer & 9 & 0,2 & Perawatan \\
14. & Pipa Bahan Bakar & 13 & 0,35 & Perbaikan \\
15. & Pipa Pendingin & 15 & 0,15 & Perbaikan \\
16. & Emergency Doppler Speed Log & 20 & 0,85 & Perbaikan \\
17. & Lampu Navigasi & 20 & 0,7 & Perbaikan \\
18. & Sextan & 6 & 0,45 & Perawatana \\
19. & Bel & 12 & 0,2 & Perbaikan \\
20. & Hand lead & 2 & 0,15 & Perawatan \\
21. & Propeller & 4 & 0,25 & Perawatan \\
22. & Parachute Distress Signal & 18 & 0,4 & Perawatan \\
23. & Walkie Talkeie & 10 & 0,8 & Perawatan \\
24. & Power Supply & 24 & 0,85 & \\
25. & Aton Controller Panel (Standard) & 19 & 0,75 & \\
\hline & & & & \\
\end{tabular}

\subsection{Penerapan Algoritma K-Means}

Berdasarkan data dan langkah-langkah yang ada di atas maka akan dilakukan pemilihan 3 centroid awal sebagai proses inisialisasi yaitu:

Tabel 2. Pemilihan Centroid Secara Acak

\begin{tabular}{ccc}
\hline Centroid & Jam Operasi Alat & Frekuensi Kerusakan \\
\hline $\mathrm{C}_{1}$ & 2 & 0,1 \\
$\mathrm{C}_{2}$ & 12 & 0,25 \\
$\mathrm{C}_{3}$ & 24 & 0,85 \\
\hline
\end{tabular}

Cluster 1 : diambil dari data ke-6

Cluster 2 : diambil dari data ke-2

Cluster 3 : diambil dari data ke-24

Menghitung jarak setiap data ke centroid terdekat, centroid terdekat akan menjadi cluster yang diikuti oleh data tersebut. Berikut ini akan dihitung jarak data pertama ke pusat cluster pertama Iterasi 1 :

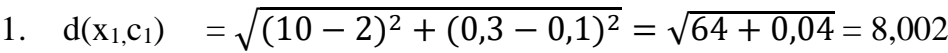

$\mathrm{d}\left(\mathrm{x}_{1}, \mathrm{c}_{2}\right)=\sqrt{(10-12)^{2}+(0,3-0,25)^{2}}=\sqrt{4+0,0025}=2,000$

$\mathrm{d}\left(\mathrm{x}_{1}, \mathrm{c}_{3}\right)=\sqrt{(10-24)^{2}+(0,3-0,85)^{2}}=\sqrt{196+0,3025}=14,010$

2. $\mathrm{d}\left(\mathrm{x}_{2}, \mathrm{c}_{1}\right)=\sqrt{(12-2)^{2}+(0,25-0,1)^{2}}=\sqrt{100+0,36}=12,014$

$\mathrm{d}\left(\mathrm{x}_{2}, \mathrm{c}_{2}\right)=\sqrt{(12-12)^{2}+(0,25-0,25)^{2}}=0,000$

$\mathrm{d}\left(\mathrm{x}_{2,} \mathrm{c}_{3}\right)=\sqrt{(12-24)^{2}+(0,25-0,85)^{2}}=\sqrt{144+0,36}=12,014$

3. $\mathrm{d}\left(\mathrm{x}_{3}, \mathrm{c}_{1}\right)=\sqrt{(8-2)^{2}+(0,5-0,1)^{2}}=\sqrt{36+0,16}=6,013$

$\mathrm{d}\left(\mathrm{x}_{3}, \mathrm{c}_{2}\right)=\sqrt{(8-12)^{2}+(0,5-0,25)^{2}}=\sqrt{16+0,0625}=4,007$

$\mathrm{d}\left(\mathrm{x}_{3,} \mathrm{c}_{3}\right)=\sqrt{(8-24)^{2}+(0,5-0,85)^{2}}=\sqrt{256+0,1225}=16,003$

Proses pada iterasi pertama dilanjutkan sampai dengan pencarian jarak pada data ke 25 (x25) terhadap masing - masing titik pusat cluster. Dari perhitungan di atas maka hasilnya dapat di bentuk kedalam tabel centroid 
untuk menentukan cluster 1 , cluster 2 , dan cluster 3, jarak terdekat dengan cluster serta menentukan cluster yang diikuti sebagai berikut :

Tabel 3. Hasil Alokasi Data Ke Klaster Jarak Ke Centroid

\begin{tabular}{|c|c|c|c|c|c|}
\hline $\begin{array}{l}\text { Data } \\
\text { ke-i }\end{array}$ & $\begin{array}{c}\text { Cluster } \\
1 \\
\end{array}$ & $\begin{array}{c}\text { Cluster } \\
2 \\
\end{array}$ & $\begin{array}{c}\text { Cluster } \\
3 \\
\end{array}$ & $\begin{array}{c}\text { Jarak Centroid } \\
\text { terdekat }\end{array}$ & $\begin{array}{c}\text { Cluster yang } \\
\text { diikuti }\end{array}$ \\
\hline 1. & 8,002 & 2,000 & 14,010 & 2,000 & 2 \\
\hline 2. & 10,001 & 0,000 & 12,014 & 0,000 & 2 \\
\hline 3. & 6,013 & 4,007 & 16,003 & 4,007 & 2 \\
\hline 4. & 10,004 & 0,15 & 12,008 & 0,15 & 2 \\
\hline 5. & 22,005 & 12,005 & 0,25 & 0,25 & 3 \\
\hline 6. & 0,000 & 10,001 & 22,012 & 0,000 & 1 \\
\hline 7. & 10,000 & 0,1 & 12,020 & 0,1 & 2 \\
\hline 8. & 0,1 & 10,000 & 22,009 & 0,1 & 1 \\
\hline 9. & 8,001 & 2 & 14,012 & 2 & 2 \\
\hline 10. & 5,003 & 5,000 & 17,008 & 5,000 & 2 \\
\hline 11. & 3,020 & 7,002 & 10,004 & 3,020 & 1 \\
\hline 12. & 1,011 & 9 & 21,008 & 9 & 2 \\
\hline 13. & 7,000 & 3,000 & 15,014 & 3,000 & 2 \\
\hline 14. & 11.002 & 1,004 & 11,011 & 1,004 & 2 \\
\hline 15. & 13,000 & 3,001 & 9,027 & 3,001 & 2 \\
\hline 16. & 18,015 & 8,022 & 4 & 4 & 3 \\
\hline 17. & 18,009 & 8,012 & 4,002 & 4,002 & 3 \\
\hline 18. & 4,015 & 6,003 & 18,004 & 4,015 & 1 \\
\hline 19. & 10,000 & 0,05 & 12,017 & 0,05 & 2 \\
\hline 20. & 0,05 & 10,000 & 22,011 & 0,05 & 1 \\
\hline 21. & 2,005 & 8 & 20,008 & 8 & 2 \\
\hline 22. & 16,002 & 6,001 & 6,016 & 6,001 & 2 \\
\hline 23. & 8,030 & 2,074 & 14,000 & 2,074 & 2 \\
\hline 24. & 22,012 & 12,014 & 0,000 & 0,000 & 3 \\
\hline 25. & 17,012 & 7,017 & 6,000 & 6,000 & 3 \\
\hline
\end{tabular}

Dari hasil data yang dipermulasikan di klaster 1, 2, dan 3 maka data tersebut dimasukkan kedalam tabel cluster 1 , tabel cluster 2 , dan tabel cluster 3 . Berikut ini merupakan data klaster yang pertama sebanyak 5:

Tabel 4. Pengelompokan cluster yang ke-1 data set

\begin{tabular}{ccccc}
\hline $\begin{array}{c}\text { Data } \\
\text { Ke-i }\end{array}$ & $\begin{array}{c}\text { Perlengkapan Alat- } \\
\text { Alat Kapal }\end{array}$ & $\begin{array}{c}\text { Jam Operasi } \\
\text { Alat }\end{array}$ & $\begin{array}{c}\text { Frekuensi } \\
\text { Kerusakan }(\%)\end{array}$ & $\begin{array}{c}\text { Perencanaan } \\
\text { Kegiatan Rutin }\end{array}$ \\
\hline 6. & Sistem Pemadam & 2 & 0,1 & Perbaikan \\
8. & Suling Kapal & 2 & 0,2 & Perbaikan \\
11. & Bolder & 5 & 0,45 & Perawatan \\
18. & Sextan & 6 & 0,45 & Perbaikan \\
20. & Hand Lead & 2 & 0,15 & Perbaikan \\
\hline
\end{tabular}

Berikut ini merupakan data klaster yang kedua sebanyak 15 :

Tabel 5. pengelompokan cluster yang ke-2 Data Set

\begin{tabular}{ccccc}
\hline $\begin{array}{c}\text { Data } \\
\text { Ke-i }\end{array}$ & $\begin{array}{c}\text { Perlengkapan Alat-Alat } \\
\text { Kapal }\end{array}$ & $\begin{array}{c}\text { Jam Operasi } \\
\text { Alat }\end{array}$ & $\begin{array}{c}\text { Frekuensi } \\
\text { Kerusakan }(\%)\end{array}$ & $\begin{array}{c}\text { Perencanaan } \\
\text { Kegiatan Rutin }\end{array}$ \\
\hline 1. & Daun/Tongkat Kemudi & 10 & 0,3 & Perawatan \\
2. & Jangkar/Rantai Sistem & 12 & 0,25 & Perawatan \\
3. & Sistem Pengeras Suara & 8 & 0,5 & Perbaikan \\
4. & Gps navigator & 12 & 0,4 & Perawatan \\
7. & Tetrahed Radar Reflector & 12 & 0,15 & Perawatan \\
9. & Radar Kapal & 10 & 0,25 & Perawatan \\
10. & Sekat & 7 & 0,3 & Perbaikan \\
12. & Transmitter & 3 & 0,25 & Perbaikan \\
13. & Clinometer & 9 & 0,2 & Perawatan \\
14. & Pipa Bahan Bakar & 13 & 0,35 & Perbaikan \\
15. & Pipa Pendingin & 15 & 0,15 & Perbaikan \\
\hline
\end{tabular}




\begin{tabular}{|c|c|c|c|c|}
\hline $\begin{array}{l}\text { Data } \\
\text { Ke-i }\end{array}$ & $\begin{array}{c}\text { Perlengkapan Alat-Alat } \\
\text { Kapal }\end{array}$ & $\begin{array}{c}\text { Jam Operasi } \\
\text { Alat }\end{array}$ & $\begin{array}{c}\text { Frekuensi } \\
\text { Kerusakan (\%) }\end{array}$ & $\begin{array}{c}\text { Perencanaan } \\
\text { Kegiatan Rutin }\end{array}$ \\
\hline 19. & Bel & 12 & 0,2 & Perawatan \\
\hline 21. & Propeller & 4 & 0,25 & Perawatan \\
\hline 22. & Parachute Distress Signal & 18 & 0,4 & Perawatan \\
\hline 23. & Walkie Talkeie & 10 & 0,8 & Perbaikan \\
\hline
\end{tabular}

Berikut ini merupakan data klaster yang pertama sebanyak 5 :

Tabel 6. pengelompokan cluster yang ke-3 Data Set

\begin{tabular}{ccccc}
\hline $\begin{array}{c}\text { Data } \\
\text { Ke-i }\end{array}$ & $\begin{array}{c}\text { Perlengkapan Alat- } \\
\text { Alat Kapal }\end{array}$ & $\begin{array}{c}\text { Jam Operasi } \\
\text { Alat }\end{array}$ & $\begin{array}{c}\text { Frekuensi } \\
\text { Kerusakan }(\%)\end{array}$ & $\begin{array}{c}\text { Perencanaan } \\
\text { Kegiatan Rutin }\end{array}$ \\
\hline 5. & Navigational Echo & 24 & 0,6 & Perbaikan \\
& $\begin{array}{c}\text { Sounder } \\
\text { Emergency Doppler }\end{array}$ & 20 & 0,85 & Perbaikan \\
16. & Speed Log & & & \\
& Lampu Navigasi & 20 & 0,7 & Perbaikan \\
17. & Power Supply & 24 & 0,85 & Perbaikan \\
24. & 19 & 0,75 & Perawatan \\
25. & $\begin{array}{c}\text { Aton Controller Panel } \\
\text { (Standard) }\end{array}$ & 19 & & \\
\hline
\end{tabular}

Rata-rata yang didapatkan dari 3 cluster tersebut adalah centroid baru yang di dapat.

Tabel 7. Centroid baru yang didapat

\begin{tabular}{ccc}
\hline Centroid & Jam Operasi Alat & Frekuensi Kerusakan (\%) \\
\hline $\mathrm{C}_{1}$ & 3,4 & 0,27 \\
$\mathrm{C}_{2}$ & 10,3 & 0,37 \\
$\mathrm{C}_{3}$ & 21,4 & 0,75 \\
\hline
\end{tabular}
diikuti.

Nilai fungsi objektif didapatkan dari Euclidean kuadrat antara setiap data dengan centroid dari cluster yang

Tabel 8. hasil simulasi K-Means dengan tabel cluster

\begin{tabular}{cccc}
\hline Data Ke-i & Cluster 1 & Cluster 2 & Cluster 3 \\
\hline 1. & 0 & 0,0949 & 0 \\
2. & 0 & 2,9044 & 0 \\
3. & 0 & 5,3069 & 0 \\
4. & 0 & 2,8909 & 0 \\
5. & 0 & 0 & 6,7825 \\
6. & 1,4289 & 0 & 0 \\
7. & 0 & 0 & 0 \\
8. & 1,4049 & 0 & 0 \\
9. & 0 & 0,1044 & 0 \\
10. & 0 & 10,8949 & 0 \\
11. & 2,5924 & 0 & 0 \\
12. & 0 & 53,3044 & 0 \\
13. & 0 & 1,7189 & 0 \\
14. & 0 & 7,2904 & 0 \\
15. & 0 & 2,9189 & 0 \\
16. & 0 & 0 & 1,97 \\
17. & 0 & 0 & 1,9625 \\
18. & 6,7924 & 0 & 0 \\
19. & 0 & 2,9189 & 0 \\
20. & 1,4144 & 0 & 0 \\
21. & 0 & 39,7044 & 0 \\
22. & 0 & 59,2909 & 0 \\
23. & 0 & 0,2749 & 0 \\
24. & 0 & 0 & 6,77 \\
25. & 0 & 0 & 5,76 \\
\hline & & &
\end{tabular}


Dari hasil iterasi 1 maka didapatkan jumlah fungsi objektif sebanyak 226,4961 yang didapatkan dengan cara menjumlahkan seluruh hasil iterasi 1, iterasi 2 dan iterasi 3, dimana pada tabel cluster 1, cluster 2 dan cluster 3 didominasi oleh cluster yang ke-1. Maka dari hasil tersebut akan dikurangi dengan cara menentukan angka acak dimana angka yang dipilih oleh penulis adalah 288,85 di simbolkan dengan X. sehingga akan mengalami perubahan fungsi objektif $\mathrm{J}$.

$\mathrm{J}=226,4961$

$\mathrm{X}=288,85$

Perubahan fungsi objektif di dapat 288,85 - 226,4961=62,3539

Karena perubahan fungsi objektif masih di atas ambang batas yang di tetapkan, maka proses dilanjutkan ke iterasi berikutnya.

Iterasi 2 :

Menghitung jarak setiap data ke centroid terdekat. Centroid terdekat akan menjadi cluster yang diikuti oleh data tersebut. Dimana data centroid baru didapatkan dari hasil rata-rata jumlah anggota setiap cluster.

Tabel 9. hasil centroid baru

\begin{tabular}{ccc}
\hline Centroid & Jam Operasi Alat & Frekuensi Kerusakan $(\%)$ \\
\hline $\mathrm{C}_{1}$ & 3,4 & 0,27 \\
$\mathrm{C}_{2}$ & 10,3 & 0,37 \\
$\mathrm{C}_{3}$ & 21,4 & 0,75
\end{tabular}

1. $\mathrm{d}\left(\mathrm{x}_{1}, \mathrm{c}_{1}\right)=\sqrt{(10-3,4)^{2}+(0,3-0,27)^{2}}=\sqrt{43,56+0,0009}=6,600$

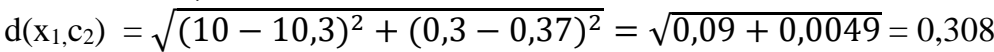

$\mathrm{d}\left(\mathrm{x}_{1}, \mathrm{c}_{3}\right)=\sqrt{(10-21,4)^{2}+(0,3-0,75)^{2}}=\sqrt{129,96+0,2025}=11,408$

2. $\mathrm{d}\left(\mathrm{x}_{2}, \mathrm{c}_{1}\right)=\sqrt{(12-3,4)^{2}+(0,25-0,27)^{2}}=\sqrt{73,96+0,0004}=8,600$

$\mathrm{d}\left(\mathrm{x}_{2}, \mathrm{c}_{2}\right)=\sqrt{(12-10,3)^{2}+(0,25-0,37)^{2}}=\sqrt{2,89+0,0144}=1,704$

$\mathrm{d}\left(\mathrm{x}_{2,} \mathrm{c}_{3}\right)=\sqrt{(12-21,4)^{2}+(0,25-0,75)^{2}}=\sqrt{88,36+0,25}=9,413$

3. $\mathrm{d}\left(\mathrm{x}_{3}, \mathrm{c}_{1}\right)=\sqrt{(8-3,4)^{2}+(0,5-0,27)^{2}}=\sqrt{21,16+0,0529}=4,605$

$\mathrm{d}\left(\mathrm{x}_{3,} \mathrm{c}_{2}\right)=\sqrt{(8-10,3)^{2}+(0,5-0,37)^{2}}=\sqrt{5,29+0,0169}=2,303$

$\mathrm{d}\left(\mathrm{x}_{3,}, \mathrm{c}_{3}\right)=\sqrt{(8-21,4)^{2}+(0,5-0,75)^{2}}=\sqrt{179,56+0,0625}=13,402$

Tabel 10. hasil alokasi data ke klaster yang ke-2 Jarak Ke Centroid

\begin{tabular}{cccccc}
\hline $\begin{array}{c}\text { Data } \\
\text { ke-i }\end{array}$ & $\begin{array}{c}\text { Cluster } \\
1\end{array}$ & $\begin{array}{c}\text { Cluster } \\
2\end{array}$ & $\begin{array}{c}\text { Cluster } \\
3\end{array}$ & $\begin{array}{c}\text { Jarak Centroid } \\
\text { terdekat }\end{array}$ & $\begin{array}{c}\text { Cluster yang } \\
\text { diikuti }\end{array}$ \\
\hline 1. & 6,600 & 0,308 & 11,408 & 0,308 & 2 \\
2. & 8,600 & 1,704 & 9,413 & 1,704 & 2 \\
3. & 4,065 & 2,303 & 13,402 & 2,303 & 2 \\
4. & 8,600 & 1,700 & 9,406 & 1,700 & 2 \\
5. & 20,602 & 13,701 & 2,604 & 2,604 & 3 \\
6. & 1,410 & 8,304 & 19,410 & 1,410 & 1 \\
7. & 8,600 & 1,714 & 9,149 & 1,714 & 2 \\
8. & 1,410 & 8,301 & 19,407 & 1,410 & 2 \\
9. & 6,600 & 0,323 & 11,410 & 0,323 & 2 \\
10. & 3,600 & 3,300 & 14,407 & 3,300 & 1 \\
11. & 1,610 & 5,300 & 16,402 & 1,610 & 2 \\
12. & 0,400 & 7,300 & 18,406 & 0,400 & 2 \\
13. & 5,600 & 1,311 & 12,412 & 1,311 & 2 \\
14. & 9,600 & 2,700 & 8,409 & 2,700 & 3 \\
15. & 11,600 & 4,705 & 6,428 & 4,705 & 3 \\
16. & 16,610 & 9,711 & 1,403 & 1,403 & 1 \\
17. & 16,605 & 9,705 & 1,400 & 1,400 & 2 \\
18. & 2,606 & 4,300 & 15,402 & 2,606 & 1 \\
19. & 8,600 & 1,708 & 9,383 & 1,708 & 3 \\
20. & 1,405 & 8,302 & 19,409 & 1,045 & 3 \\
21. & 0,600 & 6,301 & 4,201 & 0,600 & 3,417 \\
22. & 14,600 & 7,700 & 3,417 & 0,524 & 2,601 \\
23. & 6,621 & 0,524 & 11,400 & 2,4 & 2 \\
24. & 20,608 & 13,708 & 2,601 & 2,4 & 2 \\
25. & 15,607 & 8,708 & & & 2 \\
\hline
\end{tabular}


Dari hasil data yang dipermulasikan di klaster 1, 2, dan 3 pada Iterasi 2 maka data tersebut dimasukkan kedalam tabel cluster 1 , tabel cluster 2 dan tabel cluster 3 . Berikut ini merupakan data klaster yang pertama sebanyak 7 :

Tabel 11. pengelompokan cluster yang ke-1

\begin{tabular}{ccccc}
\hline $\begin{array}{c}\text { Data } \\
\text { Ke-i }\end{array}$ & $\begin{array}{c}\text { Perlengkapan Alat- } \\
\text { Alat Kapal }\end{array}$ & $\begin{array}{c}\text { Jam Operasi } \\
\text { Alat }\end{array}$ & $\begin{array}{c}\text { Frekuensi } \\
\text { Kerusakan }(\%)\end{array}$ & $\begin{array}{c}\text { Perencanaan } \\
\text { Kegiatan Rutin }\end{array}$ \\
\hline 6. & Sistem Pemadam & 2 & 0,1 & Perbaikan \\
8. & Suling Kapal & 2 & 0,2 & Perbaikan \\
11. & Bolder & 5 & 0,45 & Perawatan \\
12. & Transmitter & 3 & 0,25 & Perbaikan \\
18. & Sextan & 6 & 0,45 & Perbaikan \\
20. & Hand Lead & 2 & 0,15 & Perbaikan \\
21. & Propeller & 4 & 0,25 & Perawatan \\
\hline
\end{tabular}

Berikut ini merupakan data klaster yang kedua sebanyak 12 :

Tabel 12. pengelompokan cluster yang ke-2

\begin{tabular}{ccccc}
\hline $\begin{array}{c}\text { Data } \\
\text { Ke-i }\end{array}$ & $\begin{array}{c}\text { Perlengkapan Alat-Alat } \\
\text { Kapal }\end{array}$ & $\begin{array}{c}\text { Jam Operasi } \\
\text { Alat }\end{array}$ & $\begin{array}{c}\text { Frekuensi } \\
\text { Kerusakan(\%) }\end{array}$ & $\begin{array}{c}\text { Perencanaan } \\
\text { Kegiatan Rutin }\end{array}$ \\
\hline 1. & Daun/Tongkat Kemudi & 10 & 0,3 & Perawatan \\
2. & Jangkar/Rantai Sistem & 12 & 0,25 & Perawatan \\
3. & Sistem Pengeras Suara & 8 & 0,5 & Perbaikan \\
4. & Gps navigator & 12 & 0,4 & Perawatan \\
7. & Tetrahed Radar Reflector & 12 & 0,15 & Perawatan \\
9. & Radar Kapal & 10 & 0,25 & Perawatan \\
10. & Sekat & 7 & 0,3 & Perbaikan \\
13. & Clinometer & 9 & 0,2 & Perawatan \\
14. & Pipa Bahan Bakar & 13 & 0,35 & Perbaikan \\
15. & Pipa Pendingin & 15 & 0,15 & Perbaikan \\
19. & Bel & 12 & 0,2 & Perawatan \\
23. & Walkie Talkeie & 10 & 0,8 & Perbaikan \\
\hline
\end{tabular}

Berikut ini merupakan data klaster yang pertama sebanyak 5 :

Tabel 13. pengelompokan cluster yang ke-3

\begin{tabular}{|c|c|c|c|c|}
\hline $\begin{array}{l}\text { Data } \\
\text { Ke-i }\end{array}$ & $\begin{array}{c}\text { Perlengkapan Alat- } \\
\text { Alat Kapal }\end{array}$ & $\begin{array}{c}\text { Jam Operasi } \\
\text { Alat } \\
\end{array}$ & $\begin{array}{c}\text { Frekuensi } \\
\text { Kerusakan }(\%)\end{array}$ & $\begin{array}{c}\text { Perencanaan } \\
\text { Kegiatan Rutin } \\
\end{array}$ \\
\hline 5. & $\begin{array}{l}\text { Navigational Echo } \\
\text { Sounder }\end{array}$ & 24 & 0,6 & Perbaikan \\
\hline 16. & $\begin{array}{l}\text { Emergency Doppler } \\
\text { Speed Log }\end{array}$ & 20 & 0,85 & Perbaikan \\
\hline 17. & Lampu Navigasi & 20 & 0,7 & Perbaikan \\
\hline 22. & $\begin{array}{c}\text { Parachute Distress } \\
\text { Signal }\end{array}$ & 18 & 0,4 & Perawatan \\
\hline 24. & Power Supply & 24 & 0,85 & Perbaikan \\
\hline 25 . & $\begin{array}{c}\text { Aton Controller Panel } \\
\text { (Standard) }\end{array}$ & 19 & 0,75 & Perawatan \\
\hline
\end{tabular}

Rata-rata yang didapatkan dari 3 cluster dari Iterasi 2 tersebut adalah centroid baru yang didapat.

Tabel 14. Centroid baru yang didapat

\begin{tabular}{ccc}
\hline Centroid & Jam Operasi Alat & Frekuensi Kerusakan(\%) \\
\hline $\mathrm{C}_{1}$ & 3,4 & 0,26 \\
$\mathrm{C}_{2}$ & 10,8 & 0,32 \\
$\mathrm{C}_{3}$ & 20,8 & 0,69 \\
\hline
\end{tabular}
diikuti.

Nilai fungsi objektif didapatkan dari Euclidean kuadrat antara setiap data dengan centroid dari cluster yang 
Tabel 15. hasil simulasi K-Means tabel cluster Iterasi 2

\begin{tabular}{cccc}
\hline Data Ke-i & Cluster 1 & Cluster 2 & Cluster 3 \\
\hline 1. & 0 & 0,6404 & 0 \\
2. & 0 & 1,4449 & 0 \\
3. & 0 & 7,8724 & 0 \\
4. & 0 & 1,4464 & 10,2481 \\
5. & 0 & 0 & 0 \\
6. & 1,9856 & 0 & 0 \\
7. & 0 & 1,4689 & 0 \\
8. & 1,9636 & 0 & 0 \\
9. & 0 & 0,6449 & 0 \\
10. & 0 & 14,4404 & 0 \\
11. & 2,5961 & 0 & 0 \\
12. & 0,1601 & 0 & 0 \\
13. & 0 & 3,2544 & 0 \\
14. & 0 & 4,8409 & 0 \\
15. & 0 & 17,6689 & 0,6656 \\
16. & 0 & 0 & 0,6401 \\
17. & 0 & 0 & 0 \\
18. & 6,7961 & 0 & 0 \\
19. & 0 & 1,4544 & 0 \\
20. & 1,9721 & 0 & 0 \\
21. & 0,3601 & 0 & 7,9241 \\
22. & 0 & 0 & 0 \\
23. & 0 & 0,8704 & 3,2434 \\
24. & 0 & 0 & \\
25. & 0 & 0 & 0 \\
\hline & 0 & & 0 \\
\hline & 0 & 0 & 0 \\
\hline
\end{tabular}

Didapatkan nilai fungsi objektif $\mathrm{j}=104,86754$

Perubahan fungsi objektif di dapat 226,4961- 104,86754 = 121,62856

Karena perubahan fungsi objektif masih di atas ambang batas yang di tetapkan, maka proses dilanjutkan ke iterasi berikutnya.

Iterasi 3:

Menghitung jarak setiap data ke centroid terdekat. Centroid terdekat akan menjadi cluster yang diikuti oleh data tersebut. Dimana data centroid baru didapatkan dari hasil rata-rata jumlah anggota setiap cluster.

Tabel 16. Hasil centroid baru

\begin{tabular}{cccc}
\hline Centroid & & Jam Operasi Alat & Frekuensi Kerusakan (\%) \\
\hline & $\mathrm{C}_{1}$ & 3,4 & 0,26 \\
& $\mathrm{C}_{2}$ & 10,8 & 0,32 \\
& $\mathrm{C}_{3}$ & 20,8 & 0,69 \\
\hline
\end{tabular}

1. $\mathrm{d}\left(\mathrm{x}_{1}, \mathrm{c}_{1}\right)=\sqrt{(10-3,4)^{2}+(0,3-0,26)^{2}}=\sqrt{43,56+0,0016}=6,600$

$\mathrm{d}\left(\mathrm{x}_{1}, \mathrm{c}_{2}\right)=\sqrt{(10-10,8)^{2}+(0,3-0,32)^{2}}=\sqrt{0,64+0,0004}=0,800$

$\mathrm{d}\left(\mathrm{x}_{\left.1, \mathrm{c}_{3}\right)}=\sqrt{(10-20,8)^{2}+(0,3-0,69)^{2}}=\sqrt{116,64+0,1521}=10,807\right.$

2. $\mathrm{d}\left(\mathrm{x}_{2}, \mathrm{c}_{1}\right)=\sqrt{(12-3,4)^{2}+(0,25-0,26)^{2}}=\sqrt{73,96+0,0001}=8,600$

$\mathrm{d}\left(\mathrm{x}_{2}, \mathrm{c}_{2}\right)=\sqrt{(12-10,8)^{2}+(0,25-0,32)^{2}}=\sqrt{1,44+0,0049}=1,202$

$\mathrm{d}\left(\mathrm{x}_{2}, \mathrm{c}_{3}\right)=\sqrt{(12-20,8)^{2}+(0,25-0,69)^{2}}=\sqrt{77,44+0,1936}=8,810$

3. $d\left(x_{3}, c_{1}\right)=\sqrt{(8-3,4)^{2}+(0,5-0,26)^{2}}=\sqrt{21,16+0,0576}=7,606$

$\mathrm{d}\left(\mathrm{x}_{3}, \mathrm{c}_{2}\right)=\sqrt{(8-10,8)^{2}+(0,5-0,32)^{2}}=\sqrt{7,84+0,0324}=2,805$

$\mathrm{d}\left(\mathrm{x}_{3}, \mathrm{c}_{3}\right)=\sqrt{(8-20,8)^{2}+(0,5-0,69)^{2}}=\sqrt{163,84+0,0361}=12,801$

Tabel 17. Hasil alokasi data ke klaster yang ke-3 Jarak Ke Centroid

\begin{tabular}{cccccc}
\hline $\begin{array}{c}\text { Data } \\
\text { ke-i }\end{array}$ & $\begin{array}{c}\text { Cluster } \\
1\end{array}$ & $\begin{array}{c}\text { Cluster } \\
2\end{array}$ & $\begin{array}{c}\text { Cluster } \\
3\end{array}$ & $\begin{array}{c}\text { Jarak Centroid } \\
\text { terdekat }\end{array}$ & $\begin{array}{c}\text { Cluster yang } \\
\text { diikuti }\end{array}$ \\
\hline 1. & 6,600 & 0,800 & 10,807 & 0,800 & 2 \\
2. & 8,600 & 1,202 & 8,810 & 1,202 & 2 \\
\hline
\end{tabular}




\begin{tabular}{cccccc}
\hline $\begin{array}{c}\text { Data } \\
\text { ke-i }\end{array}$ & $\begin{array}{c}\text { Cluster } \\
1\end{array}$ & $\begin{array}{c}\text { Cluster } \\
2\end{array}$ & $\begin{array}{c}\text { Cluster } \\
3\end{array}$ & $\begin{array}{c}\text { Jarak Centroid } \\
\text { terdekat }\end{array}$ & $\begin{array}{c}\text { Cluster yang } \\
\text { diikuti }\end{array}$ \\
\hline 3. & 4,606 & 2,805 & 12,801 & 2,805 & 2 \\
4. & 8,601 & 1,202 & 8,804 & 1,202 & 2 \\
5. & 20,602 & 13,202 & 3,201 & 3,201 & 3 \\
6. & 1,409 & 8,802 & 18,809 & 1,409 & 1 \\
7. & 8,600 & 1,211 & 8,816 & 1,211 & 2 \\
8. & 1,401 & 8,800 & 18,806 & 1,401 & 1 \\
9. & 6,600 & 0,803 & 10,808 & 0,803 & 2 \\
10. & 3,600 & 3,800 & 13,807 & 3,600 & 1 \\
11. & 1,611 & 5,801 & 15,801 & 1,611 & 1 \\
12. & 0,400 & 7,800 & 17,805 & 0,400 & 1 \\
13. & 5,600 & 1,803 & 11,810 & 1,803 & 2 \\
14. & 9,600 & 2,200 & 7,807 & 2,200 & 2 \\
15. & 11,600 & 4,203 & 5,825 & 4,203 & 3 \\
16. & 16,610 & 9,215 & 0,815 & 0,815 & 1 \\
17. & 16,605 & 9,207 & 0,800 & 0,800 & 2 \\
18. & 2,606 & 4,801 & 14,801 & 2,606 & 1 \\
19. & 8,600 & 1,205 & 8,813 & 1,205 & 1 \\
20. & 1,404 & 8,801 & 18,807 & 1,404 & 3 \\
21. & 0,600 & 6,800 & 16,805 & 0,600 & 3 \\
22. & 14,600 & 7,200 & 2,814 & 2,814 & 3 \\
23. & 6,622 & 0,932 & 10,800 & 0,932 & 3,202 \\
24. & 20,608 & 13,210 & 3,203 & 1,800 & 1 \\
25. & 15,607 & 8,211 & 1,800 & & 3 \\
\hline
\end{tabular}

Dari hasil data yang dipermulasikan di klaster 1, dan 2 pada Iterasi 3 maka data tersebut dimasukkan kedalam tabel cluster 1 , dan tabel cluster 2. Berikut ini merupakan data klaster yang pertama sebanyak 9 :

Tabel 18. Pengelompokan cluster yang ke-1

\begin{tabular}{ccccc}
\hline $\begin{array}{c}\text { Data } \\
\text { Ke-i }\end{array}$ & $\begin{array}{c}\text { Perlengkapan Alat- } \\
\text { Alat Kapal }\end{array}$ & $\begin{array}{c}\text { Jam Operasi } \\
\text { Alat }\end{array}$ & $\begin{array}{c}\text { Frekuensi } \\
\text { Kerusakan }(\%)\end{array}$ & $\begin{array}{c}\text { Perencanaan } \\
\text { Kegiatan Rutin }\end{array}$ \\
\hline 6. & Sistem Pemadam & 2 & 0,1 & Perbaikan \\
8. & Suling Kapal & 2 & 0,2 & Perbaikan \\
10. & Sekat & 7 & 0,3 & Perbaikan \\
11. & Bolder & 5 & 0,45 & Perawatan \\
12. & Transmitter & 3 & 0,25 & Perbaikan \\
18. & Sextan & 6 & 0,45 & Perbaikan \\
20. & Hand Lead & 2 & 0,15 & Perbaikan \\
21. & Propeller & 4 & 0,25 & Perawatan \\
\hline
\end{tabular}

Berikut ini merupakan data klaster yang kedua sebanyak 11 :

Tabel 19. Pengelompokan cluster yang ke-2

\begin{tabular}{ccccc}
\hline $\begin{array}{c}\text { Data } \\
\text { Ke-i }\end{array}$ & $\begin{array}{c}\text { Perlengkapan Alat-Alat } \\
\text { Kapal }\end{array}$ & $\begin{array}{c}\text { Jam Operasi } \\
\text { Alat }\end{array}$ & $\begin{array}{c}\text { Frekuensi } \\
\text { Kerusakan }(\%\end{array}$ & $\begin{array}{c}\text { Perencanaan } \\
\text { Kegiatan Rutin }\end{array}$ \\
\hline 1. & Daun/Tongkat Kemudi & 10 & 0,3 & Perawatan \\
2. & Jangkar/Rantai Sistem & 12 & 0,25 & Perawatan \\
3. & Sistem Pengeras Suara & 8 & 0,5 & Perbaikan \\
4. & Gps navigator & 12 & 0,4 & Perawatan \\
7. & Tetrahed Radar Reflector & 12 & 0,15 & Perawatan \\
9. & Radar Kapal & 10 & 0,25 & Perawatan \\
13. & Clinometer & 9 & 0,2 & Perawatan \\
14. & Pipa Bahan Bakar & 13 & 0,35 & Perbaikan \\
15. & Pipa Pendingin & 15 & 0,15 & Perbaikan \\
19. & Bel & 12 & 0,2 & Perawatan \\
23. & Walkie Talkeie & 10 & 0,8 & Perbaikan \\
\hline
\end{tabular}

Berikut ini merupakan data klaster yang pertama sebanyak 5 : 
Tabel 20. Pengelompokan cluster yang ke-3

\begin{tabular}{|c|c|c|c|c|}
\hline $\begin{array}{l}\text { Data } \\
\text { Ke-i }\end{array}$ & $\begin{array}{c}\text { Perlengkapan Alat- } \\
\text { Alat Kapal }\end{array}$ & $\begin{array}{c}\text { Jam Operasi } \\
\text { Alat }\end{array}$ & $\begin{array}{c}\text { Frekuensi } \\
\text { Kerusakan (\%) }\end{array}$ & $\begin{array}{c}\text { Perencanaan } \\
\text { Kegiatan Rutin }\end{array}$ \\
\hline 5. & $\begin{array}{l}\text { Navigational Echo } \\
\text { Sounder }\end{array}$ & 24 & 0,6 & Perbaikan \\
\hline 16. & $\begin{array}{l}\text { Emergency Doppler } \\
\text { Speed Log }\end{array}$ & 20 & 0,85 & Perbaikan \\
\hline 17. & Lampu Navigasi & 20 & 0,7 & Perbaikan \\
\hline 22. & $\begin{array}{c}\text { Parachute Distress } \\
\text { Signal }\end{array}$ & 18 & 0,4 & Perawatan \\
\hline 24. & Power Supply & 24 & 0,85 & Perbaikan \\
\hline 25. & $\begin{array}{c}\text { Aton Controller Panel } \\
\text { (Standard) }\end{array}$ & 19 & 0,75 & Perawatan \\
\hline
\end{tabular}

Rata-rata yang didapatkan dari 3 cluster dari Iterasi 3 tersebut adalah centroid baru yang didapat.

Tabel 21. Centroid baru yang didapat

\begin{tabular}{ccc}
\hline Centroid & Jam Operasi Alat & Frekuensi Kerusakan (\%) \\
\hline $\mathrm{C}_{1}$ & 6,62 & 0,33 \\
$\mathrm{C}_{2}$ & 11,8 & 0,32 \\
$\mathrm{C}_{3}$ & 20,8 & 0,69 \\
\hline
\end{tabular}

Nilai fungsi objektif didapatkan dari Euclidean kuadrat antara setiap data dengan centroid dari cluster yang diikuti.

Tabel 22. Hasil simulasi K-Means tabel cluster Iterasi 3

\begin{tabular}{cccc}
\hline Data Ke-i & Cluster 1 & Cluster 2 & Cluster 3 \\
\hline 1. & 0 & 1,3928 & 0 \\
2. & 0 & 0,6773 & 0 \\
3. & 0 & 10,1448 & 0 \\
4. & 0 & 0,6788 & 0 \\
5. & 0 & 0 & 10,2481 \\
6. & 21,3973 & 0 & 0 \\
7. & 0 & 0,7013 & 0 \\
8. & 21,4142 & 0 & 0 \\
9. & 0 & 1,3973 & 0 \\
10. & 0,1453 & 0 & 0 \\
11. & 2,6388 & 0 & 0 \\
12. & 13,1108 & 0 & 0 \\
13. & 0 & 4,7668 & 0 \\
14. & 0 & 3,3133 & 0 \\
15. & 0 & 14,6213 & 0 \\
16. & 0 & 0 & 0,6656 \\
17. & 0 & 0 & 0,6401 \\
18. & 0,3988 & 0 & 0 \\
19. & 0 & 0,6868 & 0 \\
20. & 21,3768 & 0 & 0 \\
21. & 6,8708 & 0 & 0 \\
22. & 0 & 0 & 7,9241 \\
23. & 0 & 1,6228 & 0 \\
24. & 0 & 0 & 10,2656 \\
25. & 0 & 0 & 3,2434 \\
\hline
\end{tabular}

Didapatkan nilai fungsi objektif $\mathrm{j}=160,3432$

Perubahan fungsi objektif di dapat 104,86754 - 160,3432 = -55,47566 berhenti.

Karena perubahan fungsi objektif sudah di bawah ambang batas yang ditetapkan, maka proses iterasi pun 
Tabel 23. Data Hasil Analisa Cluster

\begin{tabular}{|c|c|c|c|c|}
\hline No & $\begin{array}{l}\text { Perlengkapan } \\
\text { Alat-Alat Kapal }\end{array}$ & $\begin{array}{c}\text { Jam Operasi } \\
\text { Alat }\end{array}$ & $\begin{array}{c}\text { Frekuensi } \\
\text { Kerusakan }(\%)\end{array}$ & $\begin{array}{c}\text { Perencanaan } \\
\text { Kegiatan Rutin }\end{array}$ \\
\hline 1. & Daun/Tongkat Kemudi & 10 & 0,3 & Perawatan \\
\hline 2. & Jangkar/Rantai Sistem & 12 & 0,25 & Perawatan \\
\hline 3. & Sistem Pengeras Suara & 8 & 0,5 & Perbaikan \\
\hline 4. & Gps navigator & 12 & 0,4 & Perawatan \\
\hline 5. & Navigational Echo Sounder & 24 & 0,6 & Perbaikan \\
\hline 6. & Sistem Pemadam & 2 & 0,1 & Perbaikan \\
\hline 7. & Tetrahed Radar Reflector & 12 & 0,15 & Perawatan \\
\hline 8. & Suling Kapal & 2 & 0,2 & Perbaikan \\
\hline 9. & Radar Kapal & 10 & 0,25 & Perawatan \\
\hline 10. & Sekat & 7 & 0,3 & Perbaikan \\
\hline 11. & Bolder & 5 & 0,45 & Perawatan \\
\hline 12. & Transmitter & 3 & 0,25 & Perbaikan \\
\hline 13. & Clinometer & 9 & 0,2 & Perawatan \\
\hline 14. & Pipa Bahan Bakar & 13 & 0,35 & Perbaikan \\
\hline 15. & Pipa Pendingin & 15 & 0,15 & Perbaikan \\
\hline 16. & Emergency Doppler Speed Log & 20 & 0,85 & Perbaikan \\
\hline 17. & Lampu Navigasi & 20 & 0,7 & Perbaikan \\
\hline 18. & Sextan & 6 & 0,45 & Perbaikan \\
\hline 19. & Bel & 12 & 0,2 & Perawatan \\
\hline 20. & Hand lead & 2 & 0,15 & Perbaikan \\
\hline 21. & Propeller & 4 & 0,25 & Perawatan \\
\hline 22. & Parachute Distress Signal & 18 & 0,4 & Perawatan \\
\hline 23. & Walkie Talkeie & 10 & 0,8 & Perbaikan \\
\hline 24. & Power Supply & 24 & 0,85 & Perbaikan \\
\hline 25. & Aton Controller Panel (Standard) & 19 & 0,75 & Perawatan \\
\hline
\end{tabular}

\section{KESIMPULAN}

Dari hasil penelitian dapat disimpulan, suatu perbandingan yang akhirnya dapat memberikan perbaikan-perbaikan pada masa yang akan datang. Dengan menggunakan algoritma $\mathrm{K}$-Means untuk melakukan perhitungan, ternyata mampu menyelesaikan permasalahan dalam perawatan dan perbaikan alat-alat kapal pada KN.Arcturus. Dengan memanfaatkan data mining meenggunakan algoritma $K$-Means dalam digunakan untuk mengelompokkan data yang dianalisa untuk mengetahui Tingkat kepentingan terhadap kualitas perawatan dan reparasi kapal dalam meningkatkan mutu perawatan dan perbaikan yang paling berpengaruh berturut-turut adalah pekerjaan penggantian pada alat kapal Navigational Echo Sounder, Emergency Doppler Speed Log, Lampu Navigasi, Parachute Distress Signal, Power Supply, Aton Controller Panel (Standard.

\section{REFERENCES}

[1] N. I. Febianto and N. D. Palasara, "Analisis Clustering K-Means Pada Data Informasi Kemiskinan Di Jawa Barat Tahun 2018," vol. 08, no. September, pp. 130-140, 2019.

[2] F. S. Napitupulu, I. S. Damanik, I. S. Saragih, and A. Wanto, “Algoritma K-Means Untuk Pengelompokkan Dokumen Akta Kelahiran Pada Tiap Kecamatan di Kabupaten Simalungun,” Build. Informatics, Technol. Sci., vol. 2, no. 1, pp. 5563, 2020.

[3] E. Buulolo, Data Mining Untuk Perguruan Tinggi. Deepublish, 2020.

[4] H. Sulastri and A. I. Gufroni, "Penerapan Data Mining Dalam Pengelompokan Penderita Thalassaemia," J. Nas. Teknol. dan Sist. Inf., vol. 3, no. 2, pp. 299-305, 2017.

[5] D. P. Utomo and M. Mesran, "Analisis Komparasi Metode Klasifikasi Data Mining dan Reduksi Atribut Pada Data Set Penyakit Jantung," J. Media Inform. Budidarma, vol. 4, no. 2, p. 437, 2020.

[6] E. G. Sihombing, "Klasifikasi Data Mining pada Rumah Tangga Menurut Provinsi dan Status Kepemilikan Rumah Kontrak/Sewa Menggunakan K-Means Clustering Method," J. Comput. Eng. Syst. Sci, vol. 2, no. 2, pp. 74-82, 2017.

[7] M. G. Sadewo, A. Eriza, A. P. Windarto, and D. Hartama, "Algoritma K-Means Dalam Mengelompokkan Desa / Kelurahan Menurut Keberadaan Keluarga Pengguna Listrik dan Sumber Penerangan Jalan Utama Berdasarkan Provinsi," pp. 754-761, 2019. 